\title{
Dampak Post-Truth di Media Sosial
}

\author{
Nuhdi Futuhal Arifin', A. Jauhar Fuad ${ }^{2}$ \\ ${ }^{1,2}$ Institut Agama Islam Tribakti (IAIT)Kediri \\ Inuhdi@gmail.com, ${ }^{2}$ info.ajauharfuad@gmail.com
}

\begin{abstract}
This article reviews the background of the emergence of post-truth and the impact of post-truth. This lecture uses literature review by examining various sources of reading in mass media and social media. The results of this paper explain that in Indonesia post-truth auctioning and post-election 2019 is rife on social media. Posttruth on social media does not stop there but continues to roll on various problems that exist in this country. Starting is an ethnicity, religion, and race. Hoaxes and hate speech using social media platforms as a means of spreading are not trivial matters, because the series of attacks may continue to surge. The pressure from social media often forms wild and uncontrollable opinions, which are hoped to be exploited by some groups for certain interests.
\end{abstract}

Key Word: Hate Speech, Hoax, Post Truth, Social Media

\begin{abstract}
Abstrak
Artikel ini mengulas tentang latar belakang munculnya Post-truth dan dampak dari Posttruth. Tuliasn ini menggunakan kajian pustaka dangan mengkaji berbagai sumber bacaan yang ada di media masa dan media social. Hasil tulisan ini menjelsakan bahwa di Indonesia post-truth menjelang dan pasaca pemilu 2019 marak terjadi pada media social. Post-truth di media social tidak berhenti hanya disitu tapi terus bergulir pada berbagai persoalan yang ada di negeri ini. Mulai isa suku, agama dan ras. Hoax dan ujaran kebencian menggunakan platform media sosial untuk alat penyebarannya bukan perkara sepele, karena rangkaian serangannya bisa jadi terus bergelombang. Desakan-desakan dari media sosial sering kali membentuk opni-opini liar yang tak terkendali, hal ini yang diharapkan untuk bisa dimanfaatkan oleh sebagian kelompok untuk kepentingan tertentu.
\end{abstract}

Kata Kunci: Berita Bohong, Media Sosial, Post Truth, Ujaran Kebencian

\section{Pendahuluan}

"Tuntunan jadi tontonan dan tontonan jadi tuntunan....", sebuah quotes yang begitu terkenal dari dai sejuta umat almarhum KH. Zainudin MZ seakan menjadi cermin bagi era saat ini. Ketika revolusi teknologi informasi dengan jaringan global internet seakan membuka kran akses informasi apapun dalam dunia digital, batas antara fakta dan fiksi menjadi kabur, mana yang merupakan realitas dan mana yang ilusi batasnya tipis.

Inilah era masyarakat post-modern (postmo), yang salah satu cirinya adalah 
perkembangan teknologi informasi dugaan justru juga berperan melahirkan

komunikasi begitu cepat dan canggih melalui internet. Mulai dari browser seperti mozilla, opera, chrome, UC browser. Jenis media sosial seperti facebook, twitter, youtube, instagram. Aneka gadget seperti android smartphone, aple iPhone dan iPad, google glass dan aneka inovasi teknologi lainnya ${ }^{1}$.

Membanjirnya informasi di segala sisi kehidupan manusia sebagai imbas dari percepatan teknologi membuat internet menjadi kanal informasi yang hampir tidak dapat dikontrol. ${ }^{2}$ Namun dibalik semua kemudahan akses informasi tersebut, pada saat yang sama, manusia justru kesulitan untuk mendapatkan makna dari tumpukan informasi yang didapatkannya karena kecenderungan saat ini adalah mencari pembenaran dari pada kebenaran itu sendiri. ${ }^{3}$

Perubahan pada semua aspek masyarakat post-modern inilah kemudian yang melahirkan post-truth society. Dan sayangnya fenomena post-truth adalah sebuah gejala negatif dari modernisme, sebuah fenomena wabah sosial yang menjangkiti semua elemen masyarakat. Modernisme berhasil menciptakan akses yang memudahkan manusia, namun di luar

${ }^{1}$ Eddy Cahyono Sugiarto, "Media Sosial, Post Truth, dan Literasi Digital," diakses 1 September 2020, https://setkab.go.id/media-sosial-post-truth-danliterasi-digital/.

${ }^{2}$ Sonny Eli Zaluchu, "Dinamika Hoax, Post-Truth dan Response Reader Critism Dalam Rekonstruksi Kehidupan Beragama," Religio : Jurnal Studi Agamaagama Volume 10, no. 1 (Maret 2020): 98-117.

${ }^{3}$ Eddy Cahyono Sugiarto, "Media Sosial, Post Truth, dan Literasi Digital." disrupsi informasi yang menjadi ancaman kehidupan bersosial. ${ }^{4}$

Peran media sosial semakin menjadi kebutuhan pokok yang penting bagi manusia, di setiap smartphone dipastikan terinstal beberapa aplikasi media sosial, bahkan bisa jadi dalam satu platform media sosial satu orang memiliki beberapa akun yang digunakan untuk berbagai kepentingan berbeda. Media sosial memang dirancang untuk mengumpulkan dan menjangkau banyak orang secara virtual dari berbagai kalangan usia dan latar belakang sosial. Selain digunakan sebagai sarana komunikasi bisnis seperti facebook ads, media sosial belakangan ini semakin kentara juga digunakan untuk media komunikasi politik untuk memengaruhi dan membentuk opini publik.

Penggunaan media digital, khususnya yang berbasis media sosial seringkali tidak disertai tanggung jawab sehingga tidak jarang menjadi sarana untuk penyebaran informasi yang tidak benar, hoax, fitnah, gibah, namimah, gosip, pemutarbalikan fakta, ujaran kebencian, permusuhan, kesimpangsiuran, informasi palsu yang menyebabkan disharmoni sosial yang

4 Irwan Hidayat, "Tantangan Masyarakat di Era Disrupsi," radarjember.jawapos.com, diakses 3 September 2020 , https://www.google.com/amp/s/radarjember.jawapos.c om/opini/07/12/2019/tantangan-masyarakat-di-eradisrupsi/amp/. 
menimbulkan mafsadat di tengah diminati masyarakat global saat ini ${ }^{7}$. Kondisi masyarakat. ${ }^{5}$ pertumbuhan pengakses internet baru di

Era post-truth, di mana tanpa disadari Indonesia pun tidak bisa dipandang sebelah manusia hidup dalam bayang-bayang yang mata karena ternyata berada di peringkat dianggap nyata namun sebenarnya maya, ketiga dunia setelah China dan India. Terpaut realitas yang dianggap benar namun sebenarnya sebuah kebohongan. Mengutip teori hiperealitas Jean Baudrillard dalam simulations, bahwa manusia hidup dalam simulacra, situasi simulasi berupa gambar, citra dan penanda yang menggantikan realitas pengalaman. ${ }^{6}$ Padahal gambar, citra maupun penanda bukanlah kenyataan sebenarnya. Identitas dan citra diri menjadi hal yang utama, dan orang rela meniru bahkan membeli apapun demi mendapatkan identitas dalam ruang digital, sebuah realitas identitas maya seperti yang disaksikannya dalam layar smartphone. Inilah yang disebut sebagai hiperealitas, realitas yang seolah-olah, dunia maya yang berdampak nyata.

Fakta hiperealitas ini justru semakin dikuatkan oleh survey pengguna sosial media di wilayah Asia Pasifik yang begitu tinggi sebesar 9.8\% dalam rentang Januari 2019 hingga Januari 2020, dengan penetrasi internet sebesar $9.2 \%$ menjadi bukti bahwa media sosial adalah dunia maya yang paling

\footnotetext{
5 Fatwa MUI, "Hukum Dan Pedoman Bermuamalah Melalui Media Sosial" (Komisi Fatwa Majelis Ulama Indonesia, 2017).

${ }^{6}$ Helmi Supriyatno, "Hoax dan Buzzer di Era Post-

m Truth," $24 \quad$ Februari 2020 , https://www.harianbhirawa.co.id/hoax-dan-buzzer-diera-post-truth/.
} tipis dengan pertumbuhan pengakses internet baru China sebesar 25.4 juta, Indonesia tercatat sebesar 25.3 juta pengakses internet baru dalam setahun, dengan media sosial teratas yang paling banyak diakses adalah Youtube, Facebook dan Instagram. ${ }^{8}$

Kenyataan data yang tersaji dari survey di atas, seakan menguatkan bahwa sosial media telah menjelma menjadi kehidupan kedua bagi masyarakat. Sebuah kehidupan yang bisa diciptakan dan dibentuk secara bebas oleh pemilik akun, mau tampil sebagai tokoh glamor, religius, dermawan, pemberani, cerdas, bahkan menjadi mendadak pakar yang menjadi ahlinya ahlipun bisa dengan mudah dibentuk. Media sosial adalah lahan basah untuk tumbuhnya post-truth dengan sangat cepat, ibarat tanah yang sangat subur apapun yang dilemparkan akan tumbuh dan berkembang. Krisis realitas identitas ditambah dengan peningkatan bumbu hoax menjadi pelengkap yang sempurna untuk menggambarkan kondisi masyarakat saat ini. Fakta menjadi hal yang

\footnotetext{
7 Simon Kemp, "Digital 2020: Indonesia," DataReportal, $18 \quad$ Februari 2020, https://datareportal.com/reports/didital-2020indonesia.

${ }^{8}$ Bagus Ramadhan, "Data Internet di Indonesia dan Perilakunya Tahun 2020," teknoia.com, 16 Februari 2020, https://teknoia.com/data-internet-di-indonesiadan-perilakunya-880c7bc7cd19.
} 
tidak penting, perang kepentingan semakin mengaburkan kebenaran, diperkuat oleh media sosial hingga menuai kepercayaan banyak orang. ${ }^{9}$

Menurut Fahruddin Faiz, ada tujuh akar kelahiran post-truth yaitu : (1) Manusia suka pandangan baru, kebutuhan akan dukungan eksistensi pribadi seringkali membuat manusia mencari dukungan penguat bagi identitasnya meski bersifat basa-basi dengan cara palsu dan bohong. (2) Media, kebutuhan meningkatkan rating, klik like, penambahan follower dan profit membuat media cenderung kapitalis. Memblow up berita sensasional untuk menarik pembaca demi meraup laba.

Komodifikasi, yaitu membisniskan segala sesuatu atau menjadikannya komoditas. Apapun latar belakang yang dimiliki digunakan untuk meningkatkan sisi finansial, status, posisi atau lainnya meskipun hal tersebut ditempuh dengan menebar kebohongan. (4) Kemajuan teknologi tidak diiringi adaptasi dari masyarakat maupun pemerintah, pesatnya laju teknologi tidak diimbangi peningkatan kecerdasan sosial. Komentar-komentar negatif yang dilontarkan secara iseng justru ditanggapi dengan serius sehingga memicu gejolak. (5) Pragmatisme yang berorientasi hasil jangka pendek, caracara instan untuk segera mencapai apa yang

9 Wisnu Prasetya Utomo, "Selamat Datang di Era Post-Truth," remotivi.or.id, diakses 3 September 2020, https://www.remotivi.or.id/kabar/345/selamat-datangdi-era-post-truth. diinginkan menyebabkan pembenaran melakukan tindakan-tindakan curang, menyikut kanan kiri seakan menjadi hal yang lumrah supaya melejit di tingkatan teratas. (6) Karakter masyarakat yang gampang kaget, Fahrudin Faiz mengistilahkan dengan masyarakat "epilepsi”, suka dengan hal-hal sensasional bombastis dan berebut menjadi penyebar informasi tercepat dalam komunitasnya. Seringkali tanpa dikaji, apapun berita sensasional langsung di-share padahal berita tersebut adalah kebohongan. (7) Populisme dalam politik praktis berupa sekadar retorika, untuk mendapatkan simpati masyarakat banyak sekali janji-janji indah, gagasan-gagasan muluk yang digaungkan dengan dalil 'demi rakyat' atau 'membela umat', namun sebenarnya dibalik itu semua bertujuan untuk keuntungan dirinya sendiri, mengamankan posisi jabatannya, meningkatkan image pribadinya dan lain sebagainya. ${ }^{10}$

\section{PEMBAHASAN}

\section{Hoax Bumbu Pelengkap Post-Truth}

Tentu tidak menafikan sisi positif media sosial yang terbukti mampu mengangkat dan menggerakkan sektor ekonomi dengan pesat. Mulai dari mempertemukan penjual dan pembeli secara digital dalam marketplace, promosi produk

\footnotetext{
10 Ahada Ramadhana, "Post-Truth, Peradaban Kita Hari Ini," Akurat.co, 14 Januari 2019, https://m.akurat.co/id-479901-read-posttruthperadaban-kita-hari-ini.
} 
dengan biaya hampir gratis, pemetaan kelompok dan kecenderungan konsumen yang disediakan dalam report insight media sosial menjadi pijakan data dasar yang sangat berguna bagi produsen dan masih banyak lagi yang bisa dikembangkan bagi pebisnis digital dalam media sosial, sehingga arus ekonomi kerakyatan bisa lebih melejit, tidak hanya didominasi oleh perusahaan besar.

Namun kebebasan mengunggah informasi yang disediakan media sosial kerap kali disalahgunakan untuk menyebarkan informasi kontra produktif berupa hoax, informasi palsu maupun informasi keliru yang memiliki daya rusak sosial yang dahsyat karena melibatkan sisi emosi target sebagai pemicu ledakannya. Kecenderungan masyarakat milenial adalah menerima informasi secara sekilas tanpa adanya penelaahan lebih dalam terhadap sumber dan jenis informasi yang diterimanya. Bahkan kerap kali hanya membaca judul informasi yang bombastis tanpa memahami isinya sudah langsung saja menyebarkan penggalan informasi tersebut kesemua teman-temannya.

Padahal keakuratan informasi tersebut masih tanda tanya besar. Penerima informasi seakan menutup telinga tanpa perlu menanyakan benar atau tidaknya informasi tersebut. Dengan demikian masyarakat secara tidak sadar digiring untuk semakin jauh dari fakta yang sebenarnya.

Kengganan masyarakat untuk memeriksa kebenaran suatu berita heboh dapat dilihat dari hasil survey yang dilakukan oleh Mastel pada tahun 2019. Dari hasil survey ditemukan bahwa sebanyak 55,8\% responden mengira sudah ada orang atau sistem yang memeriksa informasi yang sudah tersebar sehingga menurut mereka info yang diterima adalah informasi yang akurat. Sebanyak $37.7 \%$ responden justru tidak mau tahu dengan alasan repot atau sibuk dan terdapat pula kelompok yang unik yakni sayang kuota atau pulsa kalau untuk cek kebenaran suatu berita sebesar $6.50 \% .^{11}$

Para pembuat konten hoax dari waktu ke waktu semakin baik dalam menyamarkan fake news yang disebarkan, dalam survey tahun 2019 sebanyak 56\% menyatakan tidak selalu langsung mengetahui itu hoax pada saat menerima berita heboh. Besaran angka ini mengindikasikan bahwa hoax semakin samar untuk langsung dikenali sebagai hoax. ${ }^{12}$

Dampak hoax tidak bisa dipandang sebelah mata, karena sering kali hoax digunakan sebagai senjata ampuh bagi kepentingan politik tertentu, seperti halnya awal kemunculan post-truth pada momen politik terheboh di tahun 2016. Yakni keluarnya Inggris Raya dari Uni Eropa dan terpilihnya Donald Trump sebagai presiden AS. Cara-cara lama untuk melakukan penetrasi, intimidasi, indoktrinasi kepada

\footnotetext{
11 Mastel, "Apa yang membuat anda enggan/tidak memeriksa kebenaran berita heboh."

12 Mastel, "Langsung mengetahui itu hoax pada saat menerima berita heboh."
} 
masyarakat kini beralih dalam wadah media sosial. Penyebaran hoax dengan gencar dilakukan untuk membentuk opini yang dianggap benar oleh publik, hampir di semua platform media sosial bisa dijumpai sebaran hoax tersebut.

Meskipun dalang kepentingan dari penyebaran hoax tersebut dapat dikerucutkan, namun untuk dapat melakukan penyebaran secara masif mereka mempunyai pasukan khusus yang mengoperasikan akunakun media sosial palsu untuk menguatkan sebaran hoax yang dibuatnya. Para pengendali akun palsu ini kemudian dikenal dengan pasukan bot atau buzzer, mereka merupakan tim yang dibayar untuk membentuk opini masyarakat lewat hoax bagi kepentingan pemesan citra. Hal ini terlihat dari penelitian data yang dilakukan Soroush Vosoughi seorang ilmuan data MIT selama rentang 12 tahun menemukan 126.000 topik berita palsu dibagikan di Twitter 4,5 juta kali oleh sekitar 3 juta orang. ${ }^{13}$

Dengan demikian media sosial kini telah menjadi medan perang virtual, perang identitas, perang kepentingan, perang pencitraan, perang ideologi hingga perang "urat saraf" (debat tanpa ujung) semua bebas berpendapat melalui platform media sosial

\footnotetext{
${ }^{13}$ Edo Juvano, "Memikirkan Kembali Regulasi Media Sosial di Era Post-truth,” opini.id, 5 Maret 2020, https://www.google.com/amp/s/opini.id/amp/politik/re ad-14285/memikirkan-kembali-regulasi-media-sosial-
} di-era-post-truth. selama tidak kehabisan jaringan internet. Saat situasi makin panas akibat penyebaran hoax, hal yang tidak bisa dihindarkan adalah maraknya ujaran kebencian yang akhirnya menjadi bara dalam sekam, menimbulkan kegaduhan sosial hingga menelan korban.

Tentu masih ingat dengan Saracen, sindikat penyebar konten ujaran kebencian bernuansa suku, agama, ras dan antar golongan melalui media sosial yang berhasil diungkap oleh Bareskrim Mabes Polri pada 2017. Massifnya hoax dan ujaran kebencian dalam bentuk provokasi, hasutan dan hinaan yang mereka sebarkan membuat masyarakat gaduh hanya dengan secuil tulisan kampanye hitam, memecah belah persatuan, memicu keributan dan mengganggu ketertiban nasional.

Jenis hoax yang banyak dijumpai di media sosial di antaranya adalah (1) Hoax Proper, yakni berita bohong yang sengaja dibuat untuk menipu masyarakat, menyerang individu atau kelompok tertentu yang tidak sejalan. (2) Click Bait, yaitu membuat judul berita yang heboh dan bombastis yang sekiranya menarik perhatian pembaca. Padahal isi beritanya seringkali tidak sesuai dengan judul yang ditulis. Sifat kebanyakan pengguna media sosial dengan minat baca rendah, dimanfaatkan oleh pembuat click bait untuk memviralkan berita bohong yang dikemas dengan judul bombastis tersebut. Karena dengan minat baca rendah kebanyakan pengguna media sosial akan 
langsung membuat kesimpulan pribadi hanya dari judul berita, tanpa membaca serta memahami isi berita yang sebenarnya. (3) Berita lama yang diangkat kembali, hoax seakan tidak pernah mati karena seringnya berita-berita lama yang diangkat kembali dengan penambahan bumbu hoax sehingga menumbuhkan kesan bahwa ada kasus baru yang merupakan rangkaian kejadian dari kasus lama yang belum terselesaikan.

Buzzer, Peraup Keuntungan dari PostTruth

Buzzer adalah individu atau akun yang memiliki kemampuan amplifikasi pesan dengan cara menarik perhatian dan atau membangun percakapan dan bergerak dengan motif tertentu. ${ }^{14}$ Pada awal kemunculannya buzzer adalah orang yang bertugas untuk mendukung promosi sebuah produk supaya citranya terbangun baik dan meningkatkan pemasaran target pasar. Kebanyakan buzzer bekerja secara tim untuk membangun opini-opini publik sesuai dengan misi produsen produk. Bayaran untuk jasa buzzer ini juga cukup tinggi antara Rp800.000-Rp1.6 juta, itupun adalah harga 3 tahun lalu. ${ }^{15}$

14 Rinaldi Camil, Natasha Hassan Attamimi, Klara Esti, "Dibalik Fenomena Buzzer : Memahami Lanskap Industri dan Pengaruh Buzzer di Indonesia" (Centre for Innovation Policy and Governance (CIPG), 2017).

15 Mohammad Rinaldi Camil, "Memahami cara kerja buzzer politik Indonesia," Oktober 2019, https://www.google.com/amp/s/theconversation.com/a $\mathrm{mp} / \mathrm{memahami-cara-kerja-buzzer-politik-indonesia-}$ 125243.

Pada saat jasa buzzer ini mulai dimanfaatkan untuk kepentingan partai politik atau tokoh politik untuk memoles citra positif mereka, angka dana yang disiapkan untuk jasa buzzer sungguh mencengangkan, yakni bisa mencapai Rp. 3 milyar untuk kontrak selama sebulan, dengan bayaran yang diterima buzzer perorangan mencapai kisaran Rp3.000.000-Rp6.000.000 untuk mendengungkan pesan yang diinginkan sang aktor politik. Dalam melancarkan aksinya, para buzzer membuat ratusan bot atau akun palsu yang mereka kendalikan sebagai alat kampanye sesuai konten pemesan jasa. Meramaikan kolom komentar, melakukan spam di forum dan grup, share artikel untuk menaikkan pencitraan pemesan atau artikel yang menjatuhkan kubu lawan. ${ }^{16}$

Dalam pertarungan kancah politik akun bot adalah senjata yang cukup efektif untuk menggiring opini publik. Disinyalir penggunaan buzzer dan bot ini marak terjadi pada Pilpres yang lalu dalam perang gagasan untuk menggerakkan opini maupun menjatuhkan kubu lawan, bahkan salah satu tim menyatakan memiliki 12.000 anggota untuk berkampanye di media sosial. ${ }^{17} \mathrm{Hal}$ ini

\footnotetext{
16 Nibras Nada Nailufar, Heru Margianto, "Akunakun Palsu yang Menggiring Opini Publik," diakses 7 September 2020 , https://www.kompas.com/tren/read/2019/10/09/10000 0665/buka-bukaan-soal-buzzer-3-akun-akun-palsuyang-menggiring-opini-publik?page=all\#page2 .

${ }_{17}$ vice.com, "Ngobrol Bareng Koordinator Bot dan Buzzer, Pemicu Polarisasi Politik Makin Panas Jelang 2019," diakses 7 September 2020,
} 
juga dikuatkan analisis Drone Emprit dengan aturan perundang-undangan.

menggunakan social network analysis yang mendeteksi sebaran hashtag yang menjadi viral, mayoritas diinisiasi akun robot. Jumlah konten yang disebarkan menggunakan akun palsu di media sosial bisa mencapai 60 hingga 120 berita perhari yang disebarkan melalui platform twitter dan facebook. ${ }^{18} \mathrm{Di}$ sinilah media sosial ibarat pedang bermata dua, di satu sisi menjadi alat pendorong perubahan dan partisipasi publik. Namun di sisi yang lain menjadi ruang gaduh tempat penyebaran beragam hoax, hasutan dan ujaran kebencian.

Strategi buzzer untuk menguatkan pesan kepada audiens kerap menggunakan tagar untuk berkicau membangun percakapan baik secara alami maupun rekayasa. Kemudian membuat atau memanfaatkan situs berita untuk meningkatkan kredibilitas konten. Serta menggunakan jaringan chatting seperti whatsapp dan telegram untuk menyebarkan konten yang sudah disiapkan.

Pemerintah sendiri melalui Kominfo tidak melarang penggunaan buzzer, selama tidak mencemarkan nama baik, tidak mengandung ujaran kebencian dan sesuai

https://www.google.com/amp/s/www.vice.co $\mathrm{m} / \mathrm{amp} /$ id_id/article/vbaga9/ngobrol-barengkoordinator-bot-dan-buzzer-pemicu-polarisasipolitik-makin-panas-jelang-2019.

18 viva.co.id, "Tipikal Buzzer Indonesia, Manfaatkan Bot dengan Sedikit Strategi," t.t., https://www.viva.co.id/amp/digital/digilife/1 222571-tipikal-buzzer-indonesia-manfaatkan-botdengan-sedikit-

$\underline{\text { strategi?page }=\text { all\&utm_medium }=\text { all-page. }}$
Kominfo hanya melakukan pengawasan dan pembersihan konten-konten negatif bersama platform dengan melakukan take down akun palsu. ${ }^{19}$

\section{Algoritma Informasi Media Sosial Memperparah Post-Truth}

Media sosial diciptakan dengan memasukkan kecerdasan buatan untuk mendeteksi perilaku penggunanya. Sebuah algoritma yang mendeteksi kecenderungan informasi yang sering dicari dan diakses oleh pengguna media sosial di antara timeline yang setiap detik disesaki oleh beragam informasi. Hal ini bertujuan untuk memunculkan jenis informasi baik berupa feed ataupun iklan yang sesuai dengan keinginan pengguna media sosial. Awalnya algoritma ini diperuntukkan bagi penayangan iklan dengan memetakan kecenderungan aktifitas pengguna terhadap informasi yang sering dicari.

Adanya algoritma informasi inilah yang kemudian kembali disalahgunakan oleh pemilik kepentingan sepihak, mulai dari untuk politik, pengaburan dan doktrinasi ideologi agama, pencitraan individu dan lain sebagainya. Hal inilah yang menjadi bahan bakar bagi pasukan bot dan para buzzer untuk

19 Rahmad Fauzan, "Memahami Propaganda \& Buzzer yang Bekerja di Medsos," 10 Juli 2019, https://m.harianjogja.com/news/read/2019/10 /07/500/1021188/memahami-propagandabuzzer-yang-bekerja-di-medsos. 
menjadi trending topik di media sosial, pemasang iklan menyasar target pasar. Media karena semakin banyak akun yang sosial sebagai platform berkumpulnya memperbincangkan topik tersebut secara manusia secara virtual menciptakan cara otomatis algoritma media sosial akan supaya penggunanya betah berlama-lama mengangkat topik tersebut sehingga menggunakan platform mereka. Salah satu kemunculannya di beranda menjadi lebih caranya adalah dengan membuang intens.

pandangan yang bertentangan dengan

Sederhananya adalah seperti ini, jika sering mencari informasi mengenai makanan maka algoritma media sosial akan mindset pengguna dan membanjiri mereka dengan postingan yang sejalan dengan keyakinan pribadi. ${ }^{20}$

mendeteksi kecenderungan pada topik makanan tersebut dengan menampilkan

\section{Dampak Post-Truth} berbagai informasi yang relevan dengan makanan. Mulai dari foto makanan, resepresep membuat makanan, penjual makanan, menyarankan untuk mem-follow akun dengan kategori makanan. Sehingga pengguna seakan dibanjiri dengan informasi segala sesuatu yang berkaitan dengan makanan, sehingga bagi pecinta makanan atau yang sekedar mencari info mengenai makanan, akan semakin larut dalam lingkaran informasi mengenai makanan tersebut. Bentuk algoritma seperti ini akhirnya akan membentuk sebuah "ruang gema" di mana penerima informasi akan terus mendapat pasokan berita yang homogen.

Fake news, hoax dan ujaran kebencian merupakan masalah besar dalam media sosial, di mana dampak buruknya meningkat dengan cepat dengan algoritma media sosial yang sebenarnya digunakan monitoring target iklan untuk membantu

\section{Bila tidak}

Bila tidak dikendalikan, post-truth akan menjadi sangat berbahaya, karena kebohongan yang tersistematik justru mendapat dukungan yang besar karena dianggap benar. Dalam hal ini siapapun bisa dengan mudah menjadi kambing hitam dari hoax yang sengaja diciptakan, karena bila opini publik sudah tercuci oleh doktrin yang salah maka dengan mudah akan menganggap benar kesalahan yang dilontarkan ${ }^{21}$.

Dengan potensi disinformasi yang besar di media sosial di mana banyak informasi yang tidak relevan, terfragmentasi, membuat ilusi bagi penggunanya seolah-olah menjadi pakar dalam segala hal, apapun merasa tahu, dan berhak mengomentarinya, namun dibalik itu semua jauh dari fakta yang

${ }^{20}$ Kharisma Dhimas Syuhada, "Etika Media di Era Post-Truth," Jurnal Komunikasi Indonesia Volume V, no. 1 (2017).

${ }^{21}$ serupa.id, "Post Truth adalah Kebohongan yang Menjadi Kebenaran," 2, https://www.google.com/amp/s/serupa.id/posttruth/amp/. 
sesungguhnya, munculnya citizen journalism membuat opini publik terekspos dengan mudah yang bahkan hingga memicu konflik. Masyarakat bukan lagi objek pasif sebagai audience namun juga berperan seketika menjadi produsen informasi yang mampu membentuk opini publik di media sosial. ${ }^{22}$

Beberapa dampak post-truth yang terjadi saat ini adalah: (1) Merebaknya saling curiga dalam masyarakat dengan maraknya hoax yang memicu pikiran negatif. (2) Banyak informasi tidak valid karena teknologi yang semakin murah yang memicu masyarakat yang masih awam bisa mendapatkan gadget dan jaringan internet dengan mudah sehingga lebih mudah terpapar post-truth. (3) Perubahan karakter anak di mana lebih banyak menghabiskan waktu dengan aktifitas online dan dengan mudah terpengaruh menjadi penyebar hoax secara tidak sadar. ${ }^{23}$

Post-truth yang menjadi celah bagi pemilik kepentingan kekuasaan justru memanfaatkan semaksimal mungkin media sosial untuk mengendalikan opini publik. Dengan demikian post-truth gagal mentransmisikan kebenaran pada publik, dan yang terjadi justru publik justru lebih memilih berita fiktif yang sesuai dengan

${ }^{22}$ Eddy Cahyono Sugiarto, "Media Sosial, Post Truth, dan Literasi Digital."

${ }^{23}$ Bivisyani Questibriliain, "Post Truth Era Di Kaum Millenial," diakses 4 September 2020, https://www.jojonomic.com/blog/post-truth-era/. kepentingan atau pendapatnya sebagai penguat identitas.

\section{Memerangi Hoax Meminimalisir Post- Truth}

Besarnya dampak kerugian yang disebabkan tren post-truth di media sosial, mau tidak mau harus ada yang membangun kembali kesadaran kritis masyarakat supaya lebih peka terhadap bentuk berita hoax di media sosial yang menyajikan segalanya serba cepat. Perlu sinergitas semua pihak untuk meminimalisir kebohongan yang menjadi ciri dasar dari post-truth, sebagai pengguna media sosial, harus cerdas memilah dan memilih sumber berita yang terpercaya dan tidak mudah terpancing dengan informasi yang tidak jelas sumber dan kebenarannya.

Semakin melimpahnya informasi di ruang publik yang terkadang memanipulasi fakta, membuat makin tipisnya batas pembenaran dan kebenaran. Sehingga saat ini dirasakan perlu untuk menggencarkan literasi digital secara benar, karena netizen sebenarnya mempunyai andil yang besar dalam memerangi hoax dan ujaran kebencian yang intensitasnya terus melejit di tengah fenomena post-truth, sehingga harus benar benar memiliki kecerdasan yang utuh, tidak hanya cerdas secara keilmuan namun juga cerdas secara digital; harus bisa mengenali, memahami perkembangan informasi dengan mengedepankan nilai integritas, empati 
sekaligus bersinergi untuk saling menghargai perbedaan. Kemampuan berpikir kritis dalam menyikapi berita yang viral juga dibutuhkan supaya mampu membedakan antara berita bohong dan yang faktual, konten-konten yang bisa dipercaya maupun konten yang meragukan. Bijak dalam bermedia sosial akan sangat menguntungkan bagi kesehatan jiwa dan pikiran sehingga tidak dihabiskan hanya untuk menanggapi konten yang tidak prinsip dan tidak berguna.

Langkah yang bisa diupayakan supaya terhindar dari hoax yakni aktif untuk cross-check data bila ada informasi baru yang bombastis, tidak mudah men-share ulang informasi yang belum terkonfirmasi kebenarannya. Cermati link alamat situs, hati-hati dengan judul provokatif, luangkan waktu untuk cek keaslian foto dan konten, ikut dalam group diskusi anti hoax dan lainlain. Menurut Fahrudin Faiz, kecerdasan dalam menimbang berita penting untuk dilatih supaya tidak terjebak dalam sensasi pemberitaan bombastis. Pertama, harus disadari betul bahwa setiap berita adalah konstruksi dari pembuat berita, maka dari itu penting untuk mengetahui siapa pembuat dan sumber beritanya. Kedua, harus memahami framing berita, bagaimana makna sebenarnya yang ingin disampaikan karena bisa jadi beda orang beda pula makna yang ditangkapnya. Ketiga, jeli menilai sudut pandang media, dalam membuat berita, media pasti mengulasnya dari berbagai sudut pandang, mana yang ditonjolkan dan mana yang disingkirkan untuk membentuk opini dari berita tersebut. Keempat, pahami tujuan dari berita yang dilontarkan media apakah demi keuntungan tertentu karena tidak semua media bersifat netral. Sederhananya cek kebenarannya, cek kebaikannya dan cek manfaatnya. ${ }^{24}$

Pemerintah mempunyai andil besar untuk mengerem laju post-truth dengan mengeluarkan peraturan perundangan yang jelas. Seperti halnya undang-undang ITE yang mengandung sanksi dan hukuman bagi penyalahgunaan informasi digital yang mengganggu ketertiban umum, serta melindungi warga dalam berinteraksi di dunia maya. Kominfo juga berperan aktif dengan mengeluarkan Peraturan Menteri Komunikasi dan Informatika No. 19 Tahun 2014 tentang Penanganan Situs Bermuatan Negatif. ${ }^{25}$ Sudah selayaknya penanganan menghambat penyebaran informasi hoax menjadi tugas bersama baik dalam keluarga, pemuka agama, pihak berwajib, komunitas, pemerintah dan yang paling penting dimulai dari pribadi masing-masing. ${ }^{26}$

${ }^{24}$ Ahada Ramadhana, "Post-Truth, Peradaban Kita Hari Ini."

${ }^{25}$ Kharisma Dhimas Syuhada, "Etika Media di Era Post-Truth.”

26 Dedi Rianto Rahadi, "Perilaku Pengguna dan Informasi Hoax di Media Sosial,” Jurnal Manajemen dan Kewirausahaan Volume 5, no. 1 (2017): 58-70. 


\section{Kesimpulan}

Dalam era post-truth, hoax dan ujaran kebencian menggunakan platform media sosial untuk alat penyebarannya bukan perkara sepele, karena rangkaian serangannya bisa jadi terus bergelombang. Dengan rendahnya minat baca masyarakat pengguna media sosial, membuat mereka mudah terpengaruh dengan hoax yang diulang ulang sehingga dianggap sebagai kebenaran. Desakan-desakan dari media sosial sering kali membentuk opni-opini liar yang tak terkendali, hal ini yang diharapkan untuk bisa dimanfaatkan oleh sebagian kelompok untuk kepentingan tertentu. Wacana kebohongan yang dibentuk dalam post-truth memang didedikasikan untuk mengaduk-aduk emosi sebanyak mungkin audiens.

Bagaikan keping mata uang, media sosial menghasilkan dampak positif dan negatif. Post-truth, hoax, ujaran kebencian, opini liar merupakan bagian dari tantangan di era disrupsi saat ini. Kemampuan berpikir kritis yang mampu menimbang dengan jeli fakta demi fakta, sangat dibutuhkan untuk bertahan dari gempuran informasi post-truth. Tetap kedepankan etika dalam bermedia sosial, meskipun aktifvitas dunia maya namun dampaknya sangat terasa di dunia nyata.

\section{Daftar Pustaka}

Ahada Ramadhana. "Post-Truth, Peradaban Kita Hari Ini." Akurat.co, 14 Januari 2019. https://m.akurat.co/id-479901read-posttruth-peradaban-kita-hari-ini.

Bagus Ramadhan. "Data Internet di Indonesia dan Perilakunya Tahun 2020." teknoia.com, 16 Februari 2020. https://teknoia.com/data-internet-diindonesia-dan-perilakunya880c7bc7cd19.

Bivisyani Questibriliain. "Post Truth Era Di Kaum Millenial." Diakses 4 September 2020.

https://www.jojonomic.com/blog/posttruth-era/.

Dedi Rianto Rahadi. "Perilaku Pengguna dan Informasi Hoax di Media Sosial." Jurnal Manajemen dan Kewirausahaan Volume 5, no. 1 (2017): 58-70.

Eddy Cahyono Sugiarto. "Media Sosial, Post Truth, dan Literasi Digital." Diakses 1 September 2020. https://setkab.go.id/media-sosial-posttruth-dan-literasi-digital/.

Edo Juvano. "Memikirkan Kembali Regulasi Media Sosial di Era Post-truth." opini.id, 5 Maret 2020. https://www.google.com/amp/s/opini.id /amp/politik/read-14285/memikirkankembali-regulasi-media-sosial-di-erapost-truth.

Fatwa MUI. "Hukum Dan Pedoman Bermuamalah Melalui Media Sosial." Komisi Fatwa Majelis Ulama Indonesia, 2017.

Helmi Supriyatno. "Hoax dan Buzzer di Era Post-Truth," 24 Februari 2020. https://www.harianbhirawa.co.id/hoaxdan-buzzer-di-era-post-truth/.

Irwan Hidayat. "Tantangan Masyarakat di Era

Disrupsi." radarjember.jawapos.com. Diakses 3 September 2020. https://www.google.com/amp/s/radarje mber.jawapos.com/opini/07/12/2019/ta ntangan-masyarakat-di-eradisrupsi/amp/. 
Kharisma Dhimas Syuhada. "Etika Media di Era Post-Truth." Jurnal Komunikasi Indonesia Volume V, no. 1 (2017).

Mastel. "Apa yang membuat anda enggan/tidak memeriksa kebenaran berita heboh." Infographic dipresentasikan pada Survey Hoax Masyarakat Telematika Indonesia 2019, 2019.

-. "Langsung mengetahui itu hoax pada saat menerima berita heboh." Infographic dipresentasikan pada Survey Hoax Masyarakat Telematika Indonesia 2019, 2019.

Mohammad Rinaldi Camil. "Memahami cara kerja buzzer politik Indonesia," Oktober 2019. https://www.google.com/amp/s/thecon versation.com/amp/memahami-carakerja-buzzer-politik-indonesia-125243.

Nibras Nada Nailufar, Heru Margianto. "Akun-akun Palsu yang Menggiring Opini Publik." Diakses 7 September 2020.

https://www.kompas.com/tren/read/201 9/10/09/100000665/buka-bukaan-soal-

buzzer-3-akun-akun-palsu-yangmenggiring-opinipublik?page=all\#page2 .

Nita Siti Mudawamah. "Membekali Diri Untuk Menghadapi Fenomena PostTruth." Indonesian Journal Of Academic Librarianship Volume 2, no. 2 (Februari 2018): 21-28.

Rahmad Fauzan. "Memahami Propaganda \& Buzzer yang Bekerja di Medsos," 10 Juli 2019.

https://m.harianjogja.com/news/read/20 19/10/07/500/1021188/memahamipropaganda-buzzer-yang-bekerja-dimedsos.

Rinaldi Camil, Natasha Hassan Attamimi, Klara Esti. "Dibalik Fenomena Buzzer : Memahami Lanskap Industri dan Pengaruh Buzzer di Indonesia." Centre for Innovation Policy and Governance (CIPG), 2017. serupa.id. "Post Truth adalah Kebohongan yang Menjadi Kebenaran," 2. https://www.google.com/amp/s/serupa. $\mathrm{id} /$ post-truth/amp/.
Simon Kemp. "Digital 2020: Indonesia." DataReportal, 18 Februari 2020. https://datareportal.com/reports/didital2020-indonesia.

Sonny Eli Zaluchu. "Dinamika Hoax, PostTruth dan Response Reader Critism Dalam Rekonstruksi Kehidupan Beragama." Religio: Jurnal Studi Agama-agama Volume 10, no. 1 (Maret 2020): 98-117.

vice.com. "Ngobrol Bareng Koordinator Bot dan Buzzer, Pemicu Polarisasi Politik Makin Panas Jelang 2019.” Diakses 7 September 2020. https://www.google.com/amp/s/www.v ice.com/amp/id_id/article/vbaga9/ngob rol-bareng-koordinator-bot-dan-buzzerpemicu-polarisasi-politik-makin-panasjelang-2019.

viva.co.id. "Tipikal Buzzer Indonesia, Manfaatkan Bot dengan Sedikit Strategi," t.t. https://www.viva.co.id/amp/digital/digi life/1222571-tipikal-buzzer-indonesiamanfaatkan-bot-dengan-sedikitstrategi?page=all\&utm_medium=allpage.

Wisnu Prasetya Utomo. "Selamat Datang di Era Post-Truth." remotivi.or.id. Diakses 3 September 2020. https://www.remotivi.or.id/kabar/345/s elamat-datang-di-era-post-truth. 